\title{
Groundwater vulnerability in Vietnam and innovative solutions for sustainable exploitation
}

\author{
Sụ thương tổn nước ngầm ở Việt Nam và giải pháp mới để khai thác bền vũng
}

Review paper

Stefan, Catalin*

Institute of Waste Management and Contaminated Site Treatment, Technische Universität Dresden, Pratzschwitzer Str. 15, 01795 Pirna, Germany

\begin{abstract}
With an abundant average precipitation rate, Vietnam could be considered water-reach country. Unfortunately, the non-uniform spatial and temporal distribution of rainfall, coupled with a demographic and industrial development polarized on the two major river deltas, it makes the water resources extremely vulnerable. As consequence, severe depletions of groundwater table are reported all over the country, often in the range of 1-2 m per year and more. The subsequent land subsidence is just one of the drawbacks, another being the increasing salinity of coastal aquifers as sea water level continues to rise. Under these conditions, the natural groundwater replenishment alone is not anymore able to provide for a safe water supply, different studies indicating that the groundwater exploitation in major urban agglomerations like Hanoi or Ho Chi Minh City already passed the sustainability level. The solution presented in this paper implies making use of engineered methods for enhancing the natural groundwater recharge rates by enabling better percolation rates of surface water into subsurface and thus optimizing the regional water cycle. The method known as 'managed aquifer recharge' (MAR) is introduced, together with general guidelines and tools for planning of MAR schemes, such as the newly web-based decision support system INOWAS DSS.
\end{abstract}

Với tốc độ luợng mura trung bình dồi dào, Việt Nam có thể được coi là quốc gia có nguồn nuớc trong tầm tay. Thật không may, sự phân bố không gian và thời gian không đồng đều của luợng mua, cùng với sự phát triển dân số và công nghiệp phân cưc trên hai vùng châu thổ sông lón làm cho các nguồn nước rất dễ bị tổn thưong. Vì vậy, sụ suy giảm nước ngầm nghiêm trọng được báo cáo trên khắp đất nước, thường mỗi năm giảm 1-2 m và nhiều hơn nữa. Hiện tượng sụt lún đất xảy ra sau đó chỉ là một trong nhũng hạ chế, mặt khác là độ mặn ngày càng tăng của các tầng chứa nuớc ven biển do mưc nước biển tiếp tục tăng. Dưới những điều kiện này, việc bổ sung nước ngầm tự nhiên đơn thuần không còn có thể cung úng cho một nguồn cấp nước sạch an toàn. Các nghiên cứu khác nhau cho thấy rằng việc khai thác nuớc ngầm tại các đô thị lớn nhu Hà Nội hay thành phố Hồ Chí Minh đã vurợt qua mức độ bền vũng. Giải pháp được trình bày trong bài báo này gợi ý việc sử dụng các phương pháp thiết kế để nâng cao tỷ lệ tái nạp nước ngầm tự nhiên bằng cách cho phép tỷ lệ thẩm thấu tốt hơn nước mặt vào duới bề mặt và do đó tối uu hóa chu trình nuớc trong khu vục. Phưong pháp đuợc gọi là 'tái nạp nước ngầm có quản lý' (MAR) được giới thiệu, cùng với các hương dẫn chung và các công cu để lập kế hoạch đề án MAR, ví dụ nhu hệ thống mói hố trợ quyết định dự trên kết nối mạng INOWAS_DSS.

Keywords: managed groundwater recharge, decision support system, water resources 


\section{Introduction}

Several relevant national and international studies indicate that water resources in Vietnam are not sustainable and that the climate change poses a very serious threat to the already major challenges in the water management sector. For the seek of comparison, Germany and Vietnam share several alike demographic and geographic figures: in 2008 , total population of Vietnam counted 86.1 million people spread over a total surface of $329.000 \mathrm{~km}^{2}$, while in Germany 82.4 million people live on $357.000 \mathrm{~km}^{2}$. The numbers are similar but, although decreasing from $2.5 \%$ in 1987 to $1.2 \%$ in 2008 , the population growth rate of Vietnam is still seven times higher than the rate in Germany (World Bank, 2008). This brings a rather different perspective for both governments in drafting policies and regulations for the upcoming years.

Moreover, according to the Vietnamese Ministry of Natural Resources and Environment (MONRE), the average volume per capita of water from rivers within Vietnam was in 2006 about $3,840 \mathrm{~m}^{3}$ per year (or $10,240 \mathrm{~m}^{3}$ if water inflows from outside the country are included). By taking the population growth into calculation, these figures will decrease to $2,830 \mathrm{~m}^{3}$ (internal) and 7,660 $\mathrm{m}^{3}$ (internal and extern) by 2025 . Based on criteria set by the International Water Resources Association, Vietnam could be thus included among the nations with inadequate water supply, qualification given to nations with average water availability per capita lower than $4,000 \mathrm{~m}^{3}$ per year. The figures are even more worrying when considering that out of $3,840 \mathrm{~m}^{3}$ available, only $883 \mathrm{~m}^{3}$ per capita are effectively withdrawn every year for supply to agricultural, municipal and industrial sectors (AQUASTAT, 2010). In addition, the water resources are not evenly distributed over different regions, with over $60 \%$ concentrated in the Mekong River delta and the rest of $40 \%$ spread over almost $80 \%$ of population.

When these numbers are overlaid to the high exposure risk to climatic changes, they denote a serious pressure on water resources due both to rapid overexploitation trends and natural disasters.

\section{Water stress and urgent demand for sustainable use}

Water stress occurs when, for a certain period of time, the water demand is higher that the available amount, or when the poor quality makes the water unusable. In Vietnam, as in other developing countries with high population growth rates, the water stress is driven by the increase of water utilisation, which leads to lowering of groundwater levels and locally to land subsidence issues, especially in big urban agglomerations such as Red River Delta (RRD) and Mekong Delta (MD).

\subsection{Increase of water consumption}

The groundwater reserves in Vietnam are significant but not evenly distributed between regions. The two big deltas with unconsolidated sediments (RRD and MD re- gions) and the basalt formations in the Central Highlands created high yield aquifers while the unconsolidated sediments of North and South Central Coast areas and the limestone formations in the north (Northwest and Northeast regions) provided medium yield aquifers. In the rest of country characterized by other rock types the aquifer yields are much lower (MONRE, 2010).

The question for all regions in Vietnam is whether the natural groundwater recharge can keep pace with the increasing exploitation trend. Referring to the entire country, Vietnam has a total estimated groundwater potential (natural groundwater recharge of the country's aquifers) of about 63,000 million $\mathrm{m}^{3} /$ year (World Bank, 2009). Although apparently very high, these numbers are not uniformly distributed: while the Northwest and Northeast regions have $40 \%$ of the national groundwater potential with only $13 \%$ of the total country population, agglomerated regions like RRD and MD have $23 \%$ and respectively $20 \%$ from total inhabitants but benefit of only $4 \%$ and respectively $2 \%$ of the national groundwater indicator. Considering the limited space available $(6 \%$ for RRD and $12 \%$ for MD from the total country area), the figures indicate that regions with high population density and low groundwater potential are under the highest water stress and require an additional recharge or groundwater bodies.

Moreover, this situation turns much more critical when projected in the future: in urban areas (which include substantial parts from RRD and MD regions) the drinking water consumption is estimated to be doubled in just 10 years, from 8.8 million $\mathrm{m}^{3} /$ day in 2010 to estimated 15.9 million $\mathrm{m}^{3} /$ day in 2020 (Hoc, 2009). Only in Hanoi, the water demand in 2010 has been 1.05 million $\mathrm{m}^{3} /$ day with estimations for 2020 of 1.40 million $\mathrm{m}^{3} /$ day (World Bank, 2009). Due to limited groundwater resources and low groundwater indicators, the interest of local authorities is slowly shifting toward surface water but the costs therewith could be easily underestimated.

\subsection{Lowering of groundwater tables}

Despite the large volumes of water stored in groundwater reservoirs in northern regions, concentrated extraction especially in dense regions like RRD and MD leads to dramatic lowering of groundwater tables (Nguyen and Helm, 1995; Nguyen and Nguyen, 2002; Thu and Fredlund, 2000; HTA, 2003; World Bank, 2009). This can be explained by local withdrawn in urban areas such as Hanoi and Ho Chi Minh City, with declines of more than 1 $\mathrm{m}$ per year.

In Hanoi, data from ten monitoring stations situated in the immediate vicinity of the water extraction plants was collected from 2003 to 2006 by the Institute for Science Technology and Construction Economy. Severe decline of groundwater tables was revealed at all stations, the highest trends being noted in the western and southwestern parts of city with 1.25 and $0.98 \mathrm{~m} /$ year (HTA, 2003). In MD region, groundwater level decline of over $20 \mathrm{~m}$ was recorded in Ho Chi Minh City from 1990 to 2009 (Le, 2009) with a focalized decline of 4-5 $\mathrm{m}$ from 20012006 in Thu Duc and Go Vap districts (Le, 2007) and 
$2.27 \mathrm{~m} /$ year in Binh Chanh district (World Bank, 2009). Serious decline was reported also in Can Tho city (Nuber and Stolpe, 2008) or in Ca Mau province (1.16 m/year, according to World Bank, 2009).

Overexploitation of groundwater resources does not occur only in metropolitan areas but also in agricultural areas where intensive irrigation has been practiced over the past years (D'haeze et al., 2003; D'haeze et al., 2005; Bennett and Cheesman, 2009; Johnston et al., 2010). For example, in the coffee growing areas of Central Highland region, the groundwater levels decreased recently at a rate of about $2.5 \mathrm{~m} /$ year (World Bank, 2009).

\subsection{Land subsidence}

This drawdown of piezometric heads produced an increasing stress in the underlying aquifers caused by the decrease of pore water pressure from an unbalanced recharge - discharge mechanism. This stress was coupled with the weak geological structure of the upper layers (mud, clay, peat, silt) and, as direct consequence, land subsidence cases occurred and were reported by many authors (Nguyen and Helm, 1995; Thu and Fredlund, 2000; Nguyen and Nguyen, 2002; Luu and Pham, 2008; Nguyen et al., 2009; Go et al., 2010; Duong et al., 2010; Pham, 2011) as well as media agencies nationwide (VNN, 2008; VNNB, 2008; VTB, 2011).

Several methods are employed for the measurement of land subsidence, from direct level measurements (Nguyen and Nguyen, 2002), settlements modelling (Thu and Fredlung, 1999), radar interferometry techniques (Ho et al., 2008; Nguyen et al., 2009), automatic InSAR processing (Deguchi, 2005), and direct survey on sinkholes in karst regions (Duong et al., 2010).

In Hanoi, the first land subsidence was documented in 1988-1989 when important settlements were measured at all water extraction stations (Nguyen and Helm, 1995). More recent studies have shown that land subsidence rates increase rapidly in Hanoi from October to April (HTA, 2003) but decreases slowly with time (Nguyen and Nguyen, 2002). The biggest yearly subsidence rate was observed in Thanh Cong station ( $46 \mathrm{~mm} /$ year), followed by Phap Van and Ngo Si Lien (with $29 \mathrm{~mm} /$ year). In Gia Lam (Long Bien district), the subsidence reached the rate of about $14 \mathrm{~mm} /$ year (HTA, 2003). Also in Ho Chi Minh City (MD region) land subsidence with rates from $6 \mathrm{~mm}$ per year (Le, 2009) up to $12 \mathrm{~mm}$ per year (Ho et al., 2008) was reported while one author reported subsidence of up to $28 \mathrm{~mm}$ but using only personal communications and unpublished surveys (Ho, 2008). In all these cases a correlation can be made between water extraction rates, land subsidence magnitude and the weak subsurface geology.

Nevertheless, land subsidence issues were reported not only in weak alluvial terrains like RRD or MD but also in karst regions with hard but easily dissolving carbonate rock types. Duong et al., 2010 published a collection of case studies and detailed analysis in limestone-based regions nationwide (four provinces in Northwest and Northeast regions, two in North and South Central Coast regions, and one in RRD), including the type and scale of disasters and, in some cases, solutions for prevention and risk reduction of land subsidence hazards.

\subsection{Saltwater intrusion}

Intrusion of saltwater from sea into rivers and coastal aquifers can be caused by a reduction in hydrostatic pressure when freshwater is withdrawn at a faster rate than it can be replenished naturally. The saltwater can then have a dramatic impact on the local ecosystems, can create damage to local crops and can lead to a shortage of land and freshwater sources. Large areas can face drinking water shortage issues, particularly those who rely on unconfined aquifers just above the sea level. As Vietnam possesses 3,444 $\mathrm{km}$ of coastline (from Mong Cai in the north to Ha Tien in the south, excluding the coastline of the islands) (CIA Fact Book, 2011), many authors reported intrusion of saltwater into groundwater reservoirs ( Vu and Bui, 2006; Nguyen at al., 2008a,b; Hoang et al., 2009).

Despite the overexploitation of groundwater resources, the reduction in hydrostatic pressure between surface water and groundwater can have additional important causes. Hydropower dams built upstream and used for intensive irrigation in countries like China, Laos and Cambodia decrease the river flow volume in dry season. In addition, large network of small water dams are built by farmers on rivers' upstream to protect their crops from flooding in raining season.

Although apparently beneficial for local population, water from flooding does not contribute to natural recharge of the aquifers during raining seasons and flows out into sea. During dry season, groundwater levels are low and therefore the hydraulic compensation is done by seawater. This effect is increased by diurnal and monthly tidal action, which enables intrusion of saltwater into river mouths due to differences of up to $4 \mathrm{~m}$ in the north (RRD region), 0.5 $\mathrm{m}$ in Central Highlands and $3.5 \mathrm{~m}$ in the south (MD region) ( $\mathrm{Vu}$ and Bui, 2006). The increase of sea level with over $9 \mathrm{~cm}$ in the past 30 years (Nguyen, 2007) brings an additional negative impact with serious effects. As consequence, the lowering of water levels in rivers like Mekong (MD region) and higher hydraulic pressure enables the intrusion of salt water up to $50 \mathrm{~km}$ inland during dry season and up to $20 \mathrm{~km}$ during raining season (Tateishi et al., 2007) while in the north (RRD region), the intruded distance of $0.1 \%$ salinity contour (or $1 \mathrm{~g} / 1$, the upper limit set for delimitation between salt water and freshwater) ranges in RRD region from 33-34 $\mathrm{km}$ in Thai Binh and Red River to $47 \mathrm{~km}$ in Van Uc river (Vu and Bui, 2006).

The relationship between seawater intrusion length and the groundwater discharge into the sea was also used by Nguyen (1987) for the assessment of the dynamic groundwater resources of the confined Pleistocene aquifer of the Bac Bo plain (Red River Delta in RD region). Dang (1996) conducted field tests in Ba Ria - Vung Tau province (Southeast region) for prediction of seawater intrusion by calculating the real groundwater flow in the local groundwater pumping fields while Ngo and Doan (1998) 
studied the saltwater transport kinetic in Con Dao island (Ba Ria - Vung Tau province in SE region) and the seawater intrusion potential from Hai Phong city to Ninh Binh province (RRD region).

Pham and Furukawa (2007) described the natural disasters by region as "severe" in MD, "medium" in Central Coast and Southeast regions, "light" in RRD and "none" in Northwest, Northeast and Central Highlands. Nevertheless, the intensive increase in water salinity does not lead only to a shortage in drinking water but also to a dramatic impact to the land use patterns of the affected areas and implicitly on the household incomes (Tuong et. al, 2003). According to MARD (the Vietnamese Ministry for Agriculture and Rural Development), over 620,000 ha paddy fields ( $40 \%$ of the provinces' total rice area) cultivated in 2010 with winter-spring rice have recorded damages in coastal provinces neighbouring MD region (VNN, 2010). As consequence, cropping intensity of rice (the ratio of planted area to total district area) is decreasing and farmers cultivating paddy fields shifted their interest to aquaculture, especially shrimp farms (Kotera et al., 2008), due to the less rigorous qualitative requirements (brackish water is required for shrimp farming).

\section{Sustainability through managed aquifer recharge}

The extensive use of groundwater resources caused by the increasing demand leads to an inevitable destruction of the ecological equilibrium. This means that only those groundwater resources that get replenished within a reasonable time frame are able to provide sustainable safeguarding of water supply. Nevertheless, the climate change determines modifications in precipitation characteristics: longer dry periods are followed by short heavy precipitation events which lead to a reduction of natural groundwater recharge rate and therewith a shortening of groundwater resources.

One solution for the restoration of the groundwater budget is the management of groundwater recharge by engineered solutions. This implies making use of technical methods for enhancing the natural groundwater recharge from external sources. This can be done by enabling better percolation rates of surface water into subsurface and thus optimizing the regional water cycle. The method is coined as 'managed aquifer recharge' (MAR), known also as 'artificial groundwater recharge'.

\subsection{What is MAR?}

MAR represents a sustainable method of augmenting the groundwater reservoir with surface water by using specific engineering techniques. The main objective of MGR is to preserve and enhance the groundwater resources by aiming at the following targets:

a) Balancing the water abstraction - the deficit caused by overexploitation can be artificially compensated with additional volumes of water especially in cases when natural recharge is constrained by inadequate geological settings.

b) Prevention of land subsidence - lowering of groundwater table can lead to formation of multiple void spaces in aquifers. Under gravitational pressure these empty spaces get compressed and attract land subsidence. Keeping the groundwater level at constant values will help avoiding these issues.

c) Seasonal water storage - the method can be applied to regions with extreme climatic changes. Surplus water from raining seasons can be stored in the subsurface and used later for multiple purposes (irrigations, drinking water supply etc.).

d) Control of salt water intrusion - overexploitation of groundwater resources in coastal areas leads to disturbance of natural hydraulic equilibrium between groundwater level and salty sea water, the later getting thus into the extraction wells. MAR can prevent this by creating a natural barrier and enabling thus safe exploitation of resources.

e) Improvement of water quality - by percolation through the soil layers, the quality of augmenting water is further improved by naturally occurring processes and thus suitable for re-use.

Managed infiltration of surface water into subsurface comes as an extension of the natural percolation process. Storm water but also treated wastewater of certain quality can be allowed to percolate through soil layers and benefit of further soil-aquifer-treatment (SAT).

The advantages are multiple and cover both environmental and economic aspects. First of all, storage of water underground instead of above ground is considered much safer due to reduced exposure to pollution and climatic changes. Furthermore, the subsurface offers extremely large storage capacities that would otherwise require important volumes above ground (water dams, lakes, artificial ponds etc.). The quality of groundwater in saline areas will also improve by just simply diluting the native groundwater with water of better quality and the minimisation of water loss due to avoidance of evapotranspiration can be of major importance in arid regions.

But maybe the most important long-term advantage is represented by the closed loop between water supply and urban drainage. From both environmental and economic perspective, that brings an important contribution to a sustainable development of urban regions with advanced water shortage.

\subsection{Performance criteria for MAR}

The selection of proper MAR technology is most influenced by the topographical and hydrogeological architecture of the study area. For this reason, the assessment of MAR suitability for a given location had to be done considering each representative topographical and hydrogeological feature. 
Despite geographical considerations, the performance of MGR systems is very site-specific and requires verification of several criteria. The factors contributing to MGR success were classified in supporting factors (demand for recharge, water surplus), decisional factors (qualitative and quantitative considerations), and constraining factors (technical, socio-cultural, economic and institutional). Table 1 provides an overview of these indicators together with several specific elements that were considered for the assessment of MAR suitability:

Table 1. Checklist for implementation of MAR schemes

\begin{tabular}{|c|c|c|}
\hline Factors influencing MAR & MAR criteria & What to consider \\
\hline \multirow[t]{2}{*}{ Supporting factors } & $\begin{array}{l}\text { Water stress and demand } \\
\text { for augmentation }\end{array}$ & $\begin{array}{l}\text { Water consumption } \\
\text { Lowering of groundwater table } \\
\text { Land subsidence } \\
\text { Sea water intrusion }\end{array}$ \\
\hline & $\begin{array}{l}\text { Availability of water for } \\
\text { infiltration }\end{array}$ & $\begin{array}{l}\text { Urban runoff } \\
\text { Lakes and ponds } \\
\text { Treated sewage effluent }\end{array}$ \\
\hline \multirow[t]{3}{*}{ Decisional factors } & $\begin{array}{l}\text { Hydrogeological architec- } \\
\text { ture }\end{array}$ & $\begin{array}{l}\text { Storage capacity and specific yield } \\
\text { Aquifer thickness and transmissivity } \\
\text { Depth to groundwater table } \\
\text { Aquifer confinement }\end{array}$ \\
\hline & Qualitative considerations & $\begin{array}{l}\text { Quality of source water } \\
\text { Soil aquifer treatment }\end{array}$ \\
\hline & Technical criteria & Infiltration methods \\
\hline \multirow[t]{3}{*}{ Constraining factors } & Institutional framework & $\begin{array}{l}\text { National regulations } \\
\text { Local regulations }\end{array}$ \\
\hline & Economic & $\begin{array}{l}\text { Investment costs } \\
\text { Operation and maintenance costs }\end{array}$ \\
\hline & Socio-cultural relevance & Acceptability etc. \\
\hline
\end{tabular}

\subsection{Planning MAR schemes using decision support systems}

To reduce the efforts and minimize the costs of investigating the feasibility of managed groundwater recharge applications, decision support systems (DSS) can be used to help stakeholders in taking appropriate decisions. Additionally, the consequences of global climate change will be easier to assess and optimized solutions can be proposed on a case-by-case basis (Figure 1).

\subsubsection{GIS-based DSS}

Several DSS tools are available worldwide for the assessment of groundwater management applications. The most common approaches deal with identifying suitable infiltration sites using only data sets collected by remote sensing and interpreted using geographical information systems (Chowdary et al., 2003; Rahman et al., 2010; Tiwari and Mahajan, 2012). Different thematic maps depicting various decisional factors such as terrain slope, land use and vegetation, depth to groundwater table, hydraulic gradient, soil texture, rainfall pattern, availability of source water etc. are interpreted and integrated using fuzzy logic models. The most suitable zones for MAR are then represented on a Boolean or fuzzy logic map. The method is very useful for the prediction of potential re- charge sites (Saravi et al., 2006), but it does not include any qualitative aspects of managed aquifer recharge, which can only be estimated by experimental or simulated investigations of the respective subsurface processes. The interpolation and intersection of space-oriented data sets by GIS is only a mathematical method without any process understanding and process simulation (for example, the equipotential lines obtained by GIS methods are very different than those simulated using a physical-based model).

\subsubsection{Process-oriented DSS}

Other approaches are only process-based whereas the geographical localization of the application is only regarded in terms of environmental parameters such as temperature, precipitations etc. without implying the use of GIS tools for data analysis and interpretation. In this case, the main focus relies either on the prediction and assessment of contaminant attenuation during aquifer recharge (Miller et al., 2002) or on the computer-aided simulation of processes in the subsurface zone (Gräber et al., 2006). Sharma et al. (2008) and Wang (2010) also made important contributions to the development of a groundwater recharge knowledge base by developing guidelines for the assessment of soil-aquifer treatment process performance. 


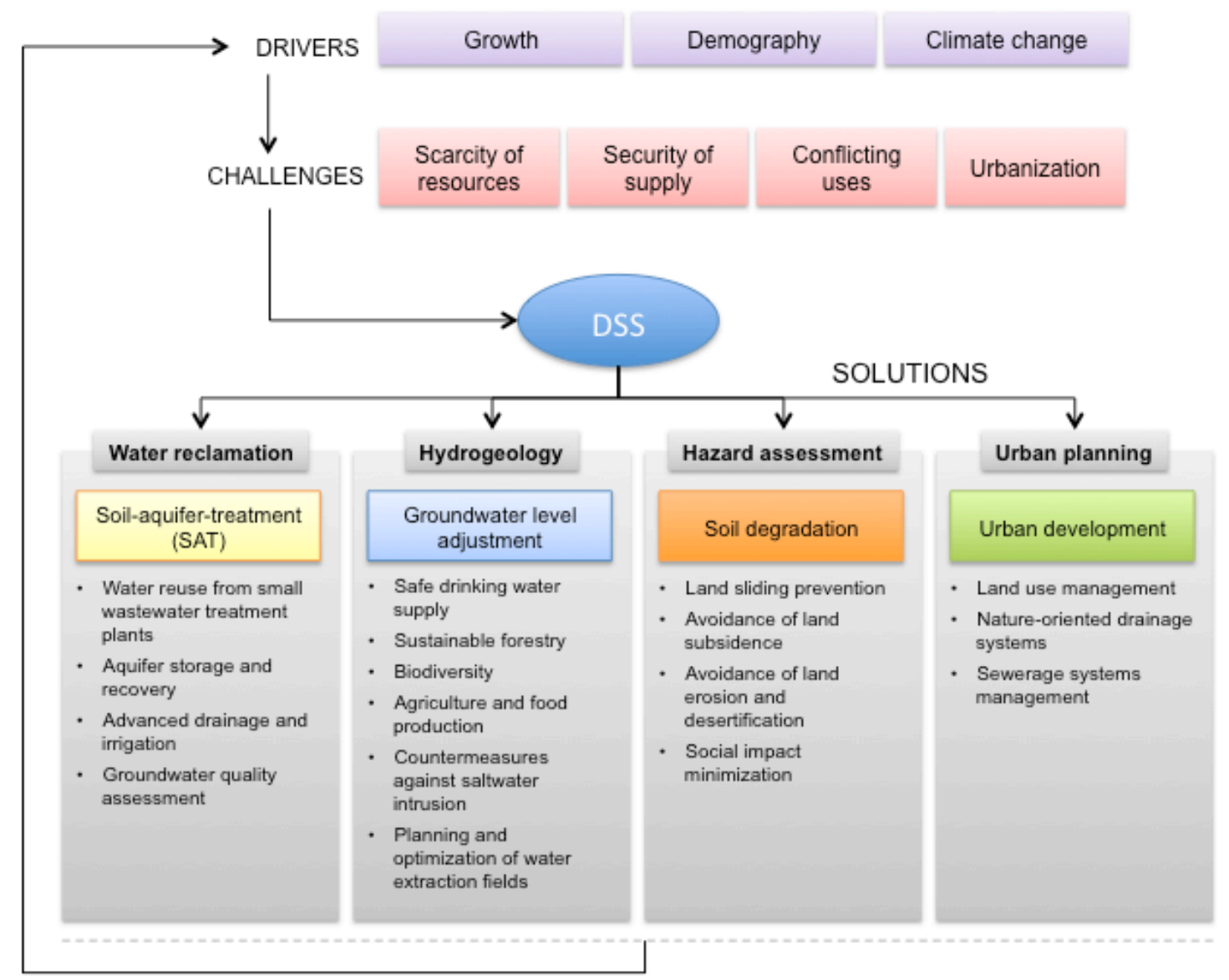

Figure 1. The role of decision support system in sustainable groundwater management

\subsubsection{GIS-based and process-oriented DSS}

In 1989, Stoertz and Bradbury used a simple groundwater flow model based on mass-balance equation, water-table elevation data, estimated hydraulic conductivity, and aquifer thickness for the elaboration of groundwater recharge / discharge patterns. Lin et al. (2003, 2009) further developed the concept by adding modern GIS analysis tools and thus combining GIS with process-based assessment of groundwater recharge. The use of such DSS tools for the evaluation of land and water uses in terms of economic, social and environmental aspects has been successfully applied in Australia (Elmahdi and McFarlane, 2009), Morocco, Tunisia, Palestinian Territories, Lebanon, Syria, Jordan (Müller et al., 2012) etc.

\subsubsection{GIS-based web DSS}

The combination of web and GIS was introduced by several authors (Ghaemi et al., 2008; Jia et al., 2009; Zhang et al., 2012) for the development of tools for sustainable environmental planning and management. Most platforms use mixed client/server system architecture to permit users the access to online geospatial databases. Similar to desktop-based systems, the approach is mostly used for the identification of suitable locations for the implementation of project-specific objectives. So far, no significant web-based applications are available for process-oriented assessment of groundwater management. Moreover, apart from geospatial data used in GIS applications, the webbased retrieval, analysis, and visualization of process- related datasets is not integrated in available environmental software applications.

\subsubsection{GIS-based, process oriented, and web GIS}

Despite the wide availability of DSS tools for planning and assessment of groundwater applications, none of them combine web-based technologies and GIS functionality with process-oriented simulation. The presented in this paper, which combines GIS functionality with qualitative and quantitative simulations, allows multi-user collaboration via internet and sharing of application results among different terminals. Even in the early development stages, the new tool will bring contributions to the understanding of consequences of climate change on sustainability of water resources, biodiversity, soil degradation, water scarcity and agricultural products, as well as development of sustainable strategies for the minimisation of the impact on soil and water resources. The web-DSS is under development under the framework of the 'INOWAS' project at Technische Universität Dresden.

\section{INOWAS_DSS}

The project 'INOWAS' started officially in May 2014 and aims at the development of a web-based decision support system for planning, design and management of human induced recharge of groundwater reservoirs. The core of the project is represented by the development of an internet platform with different modules and interconnected 
components. The system will make use of available open source applications, which will be adapted for web-based implementation.

The specific aims of the project are:

- Implementation of a decision support system (DSS) using modern web-based technology, supported by GIS functionality and process-based simulations;

- Selection, adaptation and coupling of adequate environmental models for simulation of water and solute transport through porous media;

- Development of a dynamic, comprehensive knowledge base that will make use of statistical and stochastic tools for analysis and management of the collected data;

- Collection of experimental data from infiltration scenarios run under significant combination of hydrogeological and hydrological conditions at laboratory and test-field scale;

- Application of a scale-independent methodology for the development of process-based decisional approach by normalization of experimental data and computer simulations;

- Validation and verification of simulation scenarios at selected locations;

- Internationalisation of project activities by initiation of an international network of junior researchers for the

\section{Acknowledgement}

The present paper was written within the framework of the BMBF-funded research project 'INOWAS: Innovative web-based decision support system for water sustainability under a changing climate' (www.tu-dresden.de/ uw/inowas), project no. 01LN1311A.

\section{References}

[1] World Bank (2009). TA4903-VIE Water Sector Review Project - Final Report. EEW702-FR- REP 001-Rev. 2

[2] AQUASTAT (2010). FAO's Information System on Water and Agriculture. http://www.fao.org (retrieved on 03-05-2011)

[3] MONRE (2006). Ministry of Natural Resources and Environment: National Water Resources Strategy Towards the Year 2020. Hanoi, June 2006

[4] Nguyen, H.A. (2010). Wastewater management and treatment in urban areas in Viet Nam. Presentation at the 1st WEPA International Workshop, Hanoi, Vietnam, March 9, 2000

[5] MONRE (2010). State of the Environment Report 2010. Hanoi

[6] World Bank (2008). World Development Indicators. www.data.worldbank.org/sites/default/files/ wdi08.pdf (accessed 20.10.2014)

[7] Hoc, B. (2009). Groundwater Resources Develop- promotion of DSS development during and beyond project lifetime.

The design of DSS architecture requires a careful selection, adaptation and coupling of adequate environmental models for simulation of water and solute transport through porous media. However, a common problem faced in most modelling applications is represented by data scarcity. This will be addressed in the project by using two approaches: a) development of a dynamic, comprehensive knowledge base that will make use of statistical and stochastic tools for analysis and management of the collected data, and b) development of new empirical and stochastic relations for determination of model parameters derived from laboratory experiments and field-scale investigations. By developing different upscaling techniques (normalization of experimental data and computer simulations), a scale-independent methodology will be applied for the development of processbased decisional approach (matching the applicative scenarios with the normalized calculation methods). Further, the practical tests will be used for the validation and verification of simulation scenarios at selected locations, whereas the complete, verified simulations would then be used for demonstration purposes. The initiation of an international network of young scientists and experts will enable further internationalisation or project activities and promote collaboration on the platform development during and beyond the project lifetime.

ment and Management Policy. Japan Society of Shimanto Policy and Integrated River Basin Management, 8(2): 27-35

[8] Nguyen, T.Q., Helm, D.C. (1995). Land subsidence due to groundwater withdrawal in Hanoi, Vietnam. Proceedings of the Fifth International Symposium on Land Subsidence, The Hague, October 1995.

[9] Nguyen V.D., Nguyen T.D. (2002). Groundwater Pollution in the Hanoi Area, Vietnam. ESCAP IWMI Seminar on Environmental and Public Health Risks Due to Contamination of Soils, Crops, Surface and Groundwater from Urban, Industrial and Natural Sources in South East Asia. Hanoi, Vietnam. December $10-12,2002$.

[10] Thu, T.M., Fredlund, D.G. (2000). Modeling subsidence in the Hanoi City area, Vietnam. Can. Geotech. J. 37:621-637.

[11] HTA (2003). Investigation results of assessing underground water resources. Project for increasing the capacity of Gia Lam water works to $60,000 \mathrm{~m}^{3} / \mathrm{d}$. Hanoi Transportation and Infrastructure Agency, Water Supply Company No. 2 - Main report and Annexes, Hanoi (in Vietnamese)

[12] Le, V.T. (2009). Outline of the Waterlog and Flood Prevention Solutions in Ho Chi Minh City. 7th FIG Regional Conference Spatial Data Serving People: Land Governance and the Environment - Building the Capacity Hanoi, Vietnam, October 19-22, 2009.

[13] Le, P.V. (2007): Urbanization and water management in Ho Chi Minh City, Vietnam - Issues, chal- 
lenges and perspectives. GeoJournal 70:75-89, doi 10.1007/s10708-008-9115-2.

[14] Nuber, T., Stople, H. (2008). Challenges of the groundwater management in Can Tho city, Vietnam. BGR-Symposium: Sanitation and groundwater protection. October 14-17, 2008, Hanover, Germany

[15] D'haeze, D., Deckers, J., Raes, D., Phong, T.A., Nguyen, D.M.C. (2003). Over-irrigation of Coffea canephora in the Central Highlands of Vietnam revisited: Simulation of soil moisture dynamics in Rhodic Ferralsols. Agricultural Water Management, 63(3): 185-202

[16] D’haeze, D., Raes, D., Deckers, J., Phong, T.A., Loi, H.V. (2005): Groundwater extraction for irrigation of Coffea canephora in Ea Tul watershed, Vietnam-a risk evaluation. Agricultural Water Management 73:1-19

[17] Bennett, J., Cheesman, J. (2009). Managing groundwater access in the central highlands (Tay Nguyen), Vietnam. Final report. ACIAR, Australia, ISBN: 978-1-921531-63-7.

[18] Johnston, R., Lacombe, G., Hoanh, C.T., Noble, A., Pavelic, P., Smakhtin, V., Suhardiman, D., Pheng, K.S., Sze, C.P. (2010). Climate Change, Water and Agriculture in the Greater Mekong Subregion. IWMI Research Report 136, Colombo, Sri Lanka.

[19] Luu, X.H., Pham, Q.T. (2008). Some problems on underground works for Hanoi metro projects. Report Hanoi People's Committee, Hanoi Metropolitan Rain Transport Project Board

[20] Nguyen, B.D., Minh, D.H.T., Sarti, F., Dransfeld, S., Hanssen, R. (2009): Measuring Land subsidence in Ha Noi city by means of Radar Interfeometry technique. 7th FIG Regional Conference. Spatial Data Serving People: Land Governance and the Environment - Building the Capacity. Hanoi, Vietnam, 1922 October 2009.

[21] Go, Y., Ayako, F., Susumu, N., Raghavan, V., Shoichi, O., Masumoto, S., Mamoru, S., Yumio, S. (2010). 3D Urban Model of Hanoi, Vietnam. Proceedings of GIS-IDEAS, Hanoi, Vietnam, December 9-11, 2010.

[22] Duong, T.T., Vu, C.M., Doan, V.T. (2010). Land subsidence hazard due to karst in Vietnam and mitigation measures. Proceedings of the International Symposium Hanoi Geo-engineering 2010, Hanoi, Vietnam, November 22-23, 2010.

[23] Pham, X.S. (2010). Analysis of legal framework for water use and management in Vietnam. Regional workshop "Sustainable Water Resources Use in Asia", Bangkok, December 21-22, 2010.

[24] VNN (2008). Viet Nam News: Overuse of ground water poses environmental threat to Asia. Journal online edition from 28.08.2008. http:// vietnamnews.vn/society/179884/overuse-of-groundwater-poses-environmental-threat-to-asia.html

[25] VNNB (2008). Viet Nam Net Bridge: Tower blocks, wells threaten capital city. Journal online edition from 05.12.2008

[26] VTB (2011). VietNam Today's Blog: Scientist warns of rapid land sinking in city. Journal online edition from April 28, 2008

[27] Deguchi, T. (2005). Automatic InSAR processing and Introduction of its application studies. $26^{\text {th }}$ Asian Conference on Remote Sensing, Hanoi, Vietnam, 2005.

[28] Ho, L.P. (2008). Impacts of Climate Changes and Urbanisation on Urban Inundation in Ho Chi Minh City. 11th International Conference on Urban Drainage, Edinburgh, Scotland, UK, 2008.

[29] Ho, T.M.D., Le, V.T., Sarti, F., Dransfeld, S., Hanssen, R. (2008). Measuring land subsidence in Ho Chi Minh City by means of radar interferometry techniques. International Symposium on Geoinformatics for Spatial Infrastructure Development in Earth and Allied Sciences, Hanoi, Vietnam, December 4-6, 2008.

[30] CIA Fact Book (2011). Total length of boundary between the land area and the sea. https://www.cia.gov/library/publications/the-worldfactbook/fields/2060.html (information 17.06.2011).

[31] Vu, M.C., Bui, D.D. (2006). Assessment of saline water intrusion into estuaries of Red - Thai Binh River during dry season having considered water released from upper reservoirs and tidal fluctuation. Vietnam-Japan Estuary Workshop 2006, Hanoi, Vietnam, August 22-24, 2006

[32] Nguyen, T., Vromant, N., Nguyen, T.H., Hens, L. (2008a). Organic pollution and salt intrusion in Cai Nuoc district, Ca Mau province, Vietnam. Water Environ. Res. 78(7): 716-723.

[33] Nguyen, A.D., Savenije, H.H.G., Pham, D.N., Tang, D.T. (2008b): Using salt intrusion measurements to determine the freshwater discharge distribution over the branches of a multi-channel estuary: The Mekong Delta case. Estuarine, Coastal and Shelf Science 77:433-445.

[34] Hoang, C.T., Phong, N.D., Gowing, J.W., Tuong, T.P., Ngoc, N.V., Hien, N.X. (2009). Hydraulic and water quality modeling: a tool for managing land use conflicts in inland coastal zones. Water Policy II Supplement 1, 106-120.

[35] Nguyen, H.N. (2007). Vulnerabilities, adaptation and resilience to climate change in Vietnam: capacity needs. Workshop on vulnerability, adaptation and resilience to climate risks: an assessment of education and training capacities and needs in Southeast Asia. Chiang Mai, Thailand, April 1-3, 2007.

[36] Tateishi, M., Nguyen, V.L., Ta, T.K.O., Tokuoka, T., Fukita, A., Nishimura, K., Matsuda, S. (2007). Salt water intrusion in the Mekong River estuary, Vietnam: Observation at low flow season in May 2005. Sci. Rep., Niigata Univ. (Geology) 22:57-78.

[37] Nguyen, V.H. (1987). Natural groundwater re- 
sources of Pleistocene aquifer Qa in Bac Bo plain. Report of trial working period. Institute of Geology, Natural sciences and technology of Vietnam (Former name: Institute of Geological Sciences, Academy of Sciences of Vietnam).

[38] Dang, H.O. (1996). Groundwater exploitation potential and saltwater intrusion prediction for My Xuan pumping field (Ba Ria-Vung Tau). Proceedings of the 12th Conference of Hanoi University of Mining and Geology. October 15, 1996, p. 200-203.

[39] Ngo, N.C., Doan, V.C. (1998). Groundwater exploitation potential in period up to 2010 and proposed optimal groundwater exploitation in Con Dao island. Proceedings of Geographical Researches. Institute of Geography - Natural Center for Natural Sciences and Technology of Vietnam. Science and Technology Publishing House, p. 198-205.

[40] Pham, T.T.H., Furukawa, M. (2007). Impact of sea level rise on coastal zone of Vietnam. Bull. Fac. ScL, Univ. Ryukyus 84: 45-59.

[41] Tuong, T.P., Kam, S.P., Hoanh, C.T., Dung, L.C., Khiem, N.T., Barr, J., Ben, D.C. (2003). Impact of seawater intrusion control on the environment, land use and household incomes in a coastal area. Paddy Water Environ. 1:65-73.

[42] VNN (2010). Viet Nam News: Delta needs \$12 mil to fight the drought. Journal online edition from April 5, 2010.

[43] Kotera, A., Sakamoto, T., Nguyen, D.K., Yokozawa, M. (2008). Regional Consequences of Seawater Intrusion on Rice Productivity and Land Use in Coastal Area of the Mekong River Delta. JARQ 42(4): 267-274.

[44] Chowdary, V.M., Rao, N.H., Sarma, P.B.S. (2003). GIS-based decision support system for groundwater assessment in large irrigation project areas. Agricultural Water Management 62(3): 229-252.

[45] Rahman, M.A., Rusteberg, B., Gogu, R.C., Ferreira, J.P., Sauter, M. (2010). A new spatial multi-criteria decision support tool for site selection for implementation of managed aquifer recharge. Journal of Environmental Management, 99: 61-75.

[46] Tiwari, A., Mahajan, A. (2012). Automated decision support system to identify and apply ground water recharge solutions. Proceedings of the 14th Annual International Conference and Exhibition on Geospatial Information Technology and Applications, India Geospatial Forum, 7-9 February 2012, India.

[47] Saravi, M.M., Malekian, A., Nouri, B. (2006). Identification of suitable sites for groundwater recharge. Proceedings of the 2nd International Conference on Water Resources \& Arid Environment, 26-29 November, 2006, Riyadh, Saudi Arabia.

[48] Miller, R., Corell, R., Dillon, P., and Kookana, R.S. (2002). ASRRI: A predictive index of contaminant attenuation during aquifer storage and recovery. In Proceedings of the 4th International Symposium on
Artificial Recharge of Groundwater, Adelaide, Sept 2002. Management of Aquifer Recharge for Sustainability, (P. Dillon), Lisse: Swets \& Zeitlinger: 69-74.

[49] Gräber, P.-W. et al., 2006. SiWaPro DSS Beratungssystem zur Simulation von Prozessen der unterirdischen Zonen - In: Müller, Mike - Simulation in Umwelt- und Geowissenschaften, Shaker Verlag

[50] Sharma, S.K., Harun, C.M., Amy, G. (2008): Framework for assessment of performance of soil aquifer treatment systems. Water Science and Technology 57(6): 941-946

[51] Wang, B. (2010). Development of a decision support system (DSS) for the efficiency assessment of soilaquifer-treatment (SAT) and validation on column experiments. Master Thesis, Technische Universität Dresden

[52] Stoertz, M.W., Bradbury, K.R. (1989). Mapping recharge areas using a ground-water flow model - a case study. Ground Water 27(2): 220-228

[53] Lin, Y.-F., Anderson, M.P. (2003). A digital procedure for ground water recharge and dis- charge pattern recognition and rate estimation. Ground Water 41(3): 306-315.

[54] Lin, Y.-F., Wang, J., Valocchi, A.J. (2009). PROGRADE: GIS Toolkits for Ground Water Recharge and Discharge Estimation. Ground Water 47(1): 122-128.

[55] Elmahdi, A., McFarlane, D. (2009). A decision support system for a groundwater system. Case Study: Gnangara Sustainability Strategy Western Australia. Proceedings of the 18th World IMACS / MODSIM Congress, 13-17 July 2009, Cairns, Australia.

[56] Müller, H.W., Maßmann, J., Huber, M., Subah, A., Seif, W., Droubi, A., Schelkes, K., Stork, J. (2012): Decision Support System (DSS) for Integrated Water Resources Management in the Arab Region. Investigation on climate scenarios using the WEAPMODFLOW Decision Support System. ArabGerman Cooperation Project: Management, Protection and Sustainable Use of Water and Soil Resources. 2-3 February 2012, Frankfurt, Germany.

[57] Tiwari, A., Mahajan, A. (2012). Automated decision support system to identify and apply ground water recharge solutions. Proceedings of the 14th Annual International Conference and Exhibition on Geospatial Information Technology and Applications, India Geospatial Forum, 7-9 February 2012, India.

[58] Jia, Y., Zhao, H., Niu, C., Jiang, Y., Gan, H., Xing, Z., Zhao, X., Zhao, Z. (2009). A Web GIS-based system for rainfall-runoff prediction and real-time water resources assessment for Beijing. Computers and Geosciences 35(7): 1517-1528.

[59] Zhang, H., Yi, S., Wu, Y. (2012). Decision Support System and Monitoring of Eco- Agriculture Based on WebGIS in Shule Basin. Energy Procedia 14: 382-386. 